\title{
Hydrogen peroxide in the marine boundary layer over the South Atlantic during the OOMPH cruise in March 2007
}

\author{
H. Fischer ${ }^{1}$, A. Pozzer ${ }^{1}$, T. Schmitt ${ }^{1}$, P. Jöckel ${ }^{2}$, T. Klippel ${ }^{1}$, D. Taraborrelli ${ }^{1}$, and J. Lelieveld ${ }^{1}$ \\ ${ }^{1}$ Max Planck Institute for Chemistry, Department of Atmospheric Chemistry, Mainz, Germany \\ ${ }^{2}$ Deutsches Zentrum für Luft- und Raumfahrt (DLR), Institut für Physik der Atmosphäre, Oberpfaffenhofen, Germany \\ Correspondence to: H. Fischer (horst.fischer@mpic.de)
}

Received: 06 November 2014 - Published in Atmos. Chem. Phys. Discuss.: 02 December 2014

Revised: 03 June 2015 - Accepted: 03 June 2015 - Published: 29 June 2015

\begin{abstract}
In the OOMPH (Ocean Organics Modifying Particles in both Hemispheres) project a ship measurement cruise took place in the late austral summer from 01 to 23 March 2007. The French research vessel Marion Dufresne sailed from Punta Arenas, Chile $\left(70.85^{\circ} \mathrm{W}, 53.12^{\circ} \mathrm{S}\right)$, to Réunion island $\left(55.36^{\circ} \mathrm{E}, 21.06^{\circ} \mathrm{S}\right)$ across the South Atlantic Ocean. In situ measurements of hydrogen peroxide, methylhydroperoxide and ozone were performed and are compared to simulations with the atmospheric chemistry global circulation model EMAC (ECHAM/MESSy Atmospheric Chemistry). The model generally reproduces the measured trace gas levels, but it underestimates hydrogen peroxide mixing ratios at high wind speeds, indicating too-strong dry deposition to the ocean surface. An interesting feature during the cruise is a strong increase of hydrogen peroxide, methylhydroperoxide and ozone shortly after midnight off the west coast of Africa due to an increase in the boundary layer height, leading to downward transport from the free troposphere, which is qualitatively reproduced by the model.
\end{abstract}

\section{Introduction}

The oxidizing power of the lower atmosphere in the gas phase is defined by the concentrations of the hydroxyl radical $(\mathrm{OH})$, ozone $\left(\mathrm{O}_{3}\right)$, the nitrate radical $\left(\mathrm{NO}_{3}\right)$, halogen radicals (e.g., $\mathrm{ClO}, \mathrm{BrO}, \mathrm{IO})$ and hydrogen peroxide $\left(\mathrm{H}_{2} \mathrm{O}_{2}\right)$, an important oxidizer in the liquid phase (Thompson, 1992). The dominant oxidizing agent is $\mathrm{OH}$, whose primary source is the photolysis of $\mathrm{O}_{3}$ and subsequent reaction of the formed $\mathrm{O}^{1} \mathrm{D}$ atom with water vapor (Levy, 1971). The major sinks of $\mathrm{OH}$ are reactions with carbon monoxide $(\mathrm{CO})$, methane
$\left(\mathrm{CH}_{4}\right)$ and volatile organic compounds (VOCs), yielding peroxy radicals $\left(\mathrm{HO}_{2}\right.$ and $\left.\mathrm{RO}_{2}\right)$. The fate of these peroxy radicals strongly depends on the concentrations of nitrogen oxides $\left(\mathrm{NO}_{x}\right.$, $\mathrm{NO}$ plus $\left.\mathrm{NO}_{2}\right)$. In semi-polluted and polluted regions with $\mathrm{NO}_{x}$ levels in excess of several tens of parts per trillion by volume (pptv), the peroxy radicals predominantly react with $\mathrm{NO}$, yielding $\mathrm{NO}_{2}$ and recycling $\mathrm{OH}$. In these environments the subsequent photolysis of $\mathrm{NO}_{2}$ yields ozone, with $\mathrm{NO}_{x}$ acting as a catalyst. In low- $\mathrm{NO}_{x}$ environments, such as the marine boundary layer (MBL), the peroxy radicals undergo self-reactions $\left(\mathrm{HO}_{2}+\mathrm{HO}_{2}\right.$ and $\left.\mathrm{RO}_{2}+\mathrm{HO}_{2}\right)$ yielding $\mathrm{H}_{2} \mathrm{O}_{2}$ and organic peroxides (e.g., $\mathrm{CH}_{3} \mathrm{OOH}$ from methane oxidation), and also destroying ozone $\left(\mathrm{HO}_{2}+\mathrm{O}_{3}\right.$ and $\left.\mathrm{OH}+\mathrm{O}_{3}\right)$. The peroxides serve as reservoir species for the $\mathrm{HO}_{x}\left(\mathrm{OH}\right.$ plus $\left.\mathrm{HO}_{2}\right)$ radicals, which can be recycled by photolysis or reaction with $\mathrm{OH}$. Hydrogen peroxide is also an important oxidizing agent in the liquid phase, notably of sulfur dioxide. Since many peroxides are water soluble, physical removal processes (deposition to surfaces and washout in rain events) strongly influence the oxidizing power of the lower atmosphere.

In the marine boundary layer at low $\mathrm{NO}_{x}$ concentrations the concentrations of $\mathrm{H}_{2} \mathrm{O}_{2}, \mathrm{ROOH}$ and $\mathrm{O}_{3}$ are strongly coupled, since their formation and destruction compete for the $\mathrm{HO}_{x}$ radicals. In order to model oxidation processes in this environment, formation and destruction of peroxides have to be accurately described, including the physical removal processes.

Previous measurements of peroxides $\left(\mathrm{H}_{2} \mathrm{O}_{2}\right.$ and $\left.\mathrm{ROOH}\right)$ in the marine boundary layer in the 1980s and 1990s have been summarized in the review article by Lee et al. (2000). Since this review additional observations in the marine 


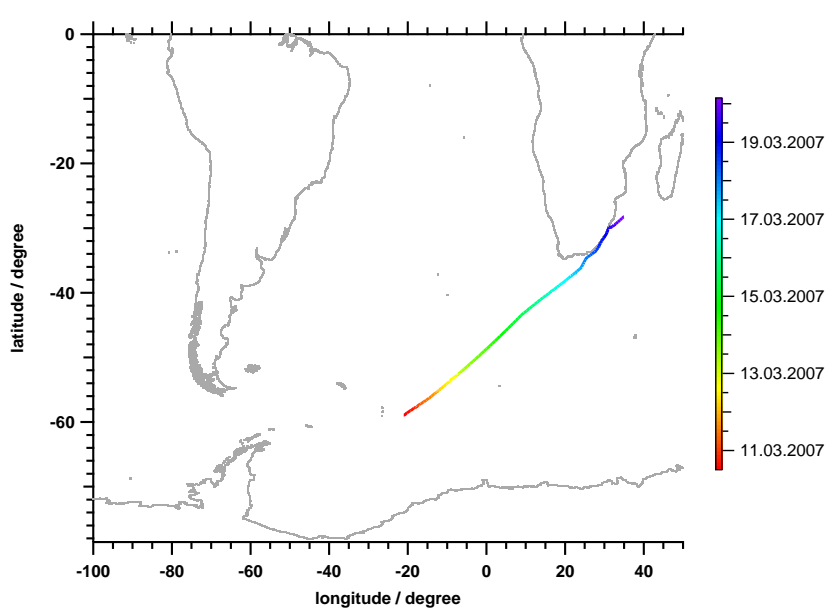

Figure 1. Ship track of the Marion Dufresne over the South Atlantic. The track is color coded with time.

boundary layer have been reported in the literature (Junkermann and Stockwell, 1999; Weller et al., 2000; Kieber et al., 2001; O'Sullivan et al., 2004; Chang et al., 2004; Stickler et al., 2007). These observations indicate highest mixing ratios ( $>500$ pptv) of $\mathrm{H}_{2} \mathrm{O}_{2}$ in the tropics (Slemr and Tremmel, 1994; Heikes et al., 1996; O'Sullivan et al., 1999, 2004; Junkermann and Stockwell, 1999; Weller et al., 2000) and decreasing concentrations toward higher latitudes in both hemispheres, reaching 200-300 pptv south of $40^{\circ}$ in the Southern Hemisphere (Slemr and Tremmel, 1994; O'Sullivan et al., 1999, 2004; Junkermann and Stockwell, 1999; Weller et al., 2000). In general mixing ratios are about a factor of 2 higher in the Northern Hemisphere than at corresponding latitudes in the south (O'Sullivan et al., 1999). A significant dissimilarity between the different ocean basins has not been observed, while higher $\mathrm{H}_{2} \mathrm{O}_{2}$ mixing ratios have been observed in continental outflow (e.g., Heikes et al., 1996).

The mixing ratios of the most abundant organic peroxide $\mathrm{CH}_{3} \mathrm{OOH}$ show similar behavior to $\mathrm{H}_{2} \mathrm{O}_{2}$ in the marine boundary layer, with highest levels in the tropics and decreasing towards the poles. Also the absolute mixing ratios are comparable, yielding $\mathrm{H}_{2} \mathrm{O}_{2} / \mathrm{CH}_{3} \mathrm{OOH}$ ratios close to 1 in air masses not affected by recent rainout (Lee et al., 2000).

Here we describe in situ ship-based observations of $\mathrm{O}_{3}$, $\mathrm{H}_{2} \mathrm{O}_{2}$ and a proxy for $\mathrm{CH}_{3} \mathrm{OOH}$ in the marine boundary layer of the South Atlantic Ocean in the austral late summer of 2007. These measurements are compared to the atmospheric chemistry global circulation model EMAC (ECHAM/MESSy Atmospheric Chemistry; Jöckel et al., 2006, 2010). Section 2 describes the methods (measurement principles and model) used, while the observations and model comparisons are described and discussed in Sect. 3. The final section summarizes the findings of this study.

\section{Methods}

\subsection{OOMPH cruise MD160}

As part of the OOMPH (Ocean Organics Modifying Particles in both hemispheres) project a measurement cruise took place in the late austral summer from 01 to 23 March 2007. The French research vessel Marion Dufresne sailed from Punta Arenas, Chile $\left(70.85^{\circ} \mathrm{W}, 53.12^{\circ} \mathrm{S}\right)$, to Réunion island $\left(55.36^{\circ} \mathrm{E}, 21.06^{\circ} \mathrm{S}\right)$, crossing the South Atlantic between the east coast of South America and the southern Indian Ocean east of southern Africa between $20^{\circ} \mathrm{W}, 60^{\circ} \mathrm{S}$ and $35^{\circ} \mathrm{E}, 35^{\circ} \mathrm{S}$ (Fig. 1). During the first part of the cruise at high southern latitudes, cold air was encountered from the Antarctic continent. During this part of the cruise, cloud cover was extensive. Further north, temperatures increased together with solar radiation intensity and photolysis frequencies. The wind was generally from the west, with wind speeds varying between calm conditions and gale force winds up to $33 \mathrm{~m} \mathrm{~s}^{-1}$. The average wind varied between more than $10 \mathrm{~m} \mathrm{~s}^{-1}$ during the first part and $8 \mathrm{~m} \mathrm{~s}^{-1}$ during the second part of the campaign (Fig. 2). Details of the cruise can be found in Williams et al. (2010) and Hosaynali Beygi et al. (2011).

\subsection{Trace gas measurements}

Data used in this study were obtained by two in situ instruments mounted in a temperature-controlled container placed on the foredeck of the ship (see Fig. 3 in Hosaynali Beygi et al., 2011). Air was sampled from the top of an atmospheric mast ( $10 \mathrm{~m}$ above the deck, $20-25 \mathrm{~m}$ above the sea surface) through $17.1 \mathrm{~m}, 0.5 \mathrm{in}$. Teflon tubes, shielded from sunlight by a black cover. The inlet was designed as a bypass with a total flow of 24 slpm (retention time $3.4 \mathrm{~s}$ ) sustained by a membrane pump. From the bypass inlet small flows were directed to the in situ instruments inside the container via short 0.25 in. Teflon lines.

Hydrogen peroxide $\left(\mathrm{H}_{2} \mathrm{O}_{2}\right)$ was measured with a commercial analyzer (AL2001 CA, Aero Laser, GarmischPartenkirchen, Germany) based on wet chemical dual enzyme detection scheme described by Lazarus et al. (1985, 1986). Gaseous peroxides are sampled in a buffered (potassium hydrogen phthalate $/ \mathrm{NaOH}$ ) sampling solution ( $\mathrm{pH} 5.8$ ) in a glass stripping coil at a flow of $3 \mathrm{slpm}$. The sampling efficiency for $\mathrm{H}_{2} \mathrm{O}_{2}$ was determined several times in the field and was always higher than 0.8. After passing the sampling coil, the degassed liquid peroxide solution is divided into two channels and subsequently reacts with p-hydroxyphenyl acetic acid (POPHA) and horseradish peroxidase. The reaction with hydrogen peroxide, organic hydroperoxides and organic peroxides yields a fluorescent dye (6,6'-dihydroxy$3,3^{\prime}$-biphenyldiacetic acid) in stoichiometric quantities that is subsequently detected via fluorescence spectroscopy at 400 $420 \mathrm{~nm}$ after excitation at $326 \mathrm{~nm}$ with a Cd ray lamp in 


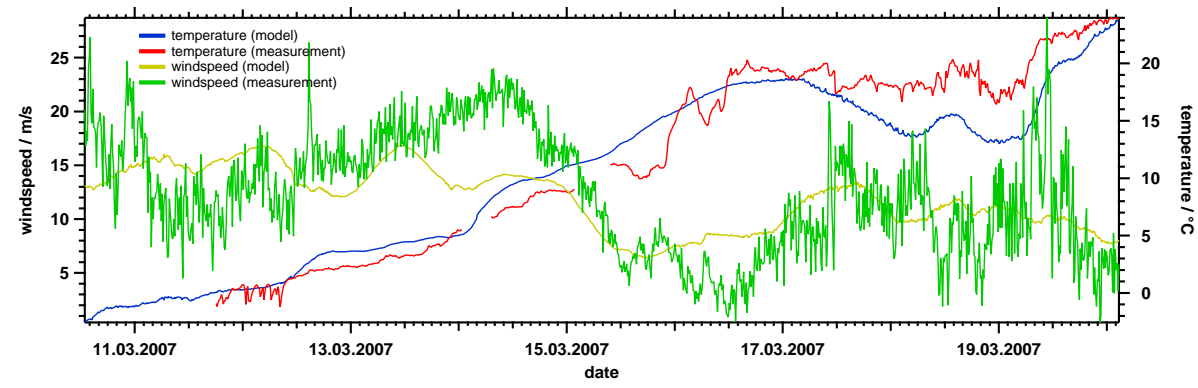

Figure 2. Time series of observed and simulated temperature and wind speed.

a detection cell. Since the detection scheme is unspecific, the $\mathrm{H}_{2} \mathrm{O}_{2}$ concentration is determined from the difference of the two channels, with channel A measuring all peroxides $(\mathrm{ROOH})$, while channel B measures $\mathrm{ROOH}-\mathrm{H}_{2} \mathrm{O}_{2}$ after selective destruction of $\mathrm{H}_{2} \mathrm{O}_{2}$ via addition of catalase (efficiency $>95 \%$ as determined in the field) prior to the reaction with POPHA. Thus the difference between the two channels provides the $\mathrm{H}_{2} \mathrm{O}_{2}$ concentration, while channel B provides an unspecific measurement of all organic hydroperoxides and organic peroxides. Nevertheless, assuming that methylhydroperoxide (MHP; $\mathrm{CH}_{3} \mathrm{OOH}$ ) is the most abundant organic peroxide in the remote marine boundary layer, as shown by previous measurements (e.g., Heikes et al., 1996), we obtain an upper limit assuming that ROOH consists of MHP only. The organic peroxide data is subsequently corrected for the lower sampling efficiency of $\mathrm{CH}_{3} \mathrm{OOH}$ compared to $\mathrm{H}_{2} \mathrm{O}_{2}$. The time resolution (10-90\%) of the instrument is $30 \mathrm{~s}$.

The in-field calibration of the instrument involves regular zero gas measurements (scrubbed ambient air after passage through cartridges filled with silica gel and hopcalite (Infiltec, Speyer, Germany)), liquid calibrations (liquid $\mathrm{H}_{2} \mathrm{O}_{2}$ standard of $35.5 \mu \mathrm{g} \mathrm{L}-1$ ) and gas-phase calibrations with a $\mathrm{H}_{2} \mathrm{O}_{2}$ permeation tube $\left(30 \% \mathrm{H}_{2} \mathrm{O}_{2}\right.$ in a glass flask temperature-controlled to $40^{\circ} \mathrm{C}$ providing a calibration gas concentration of $6.38 \mathrm{ppbv})$. The detection limit of the instrument was determined from the $1 \sigma$ variability of the infield zero measurements performed every $2.5 \mathrm{~h}$, estimated at $25 \mathrm{pptv}$. The total uncertainty determined from the precision ( $1 \sigma$ variability of nine in-field gas-phase and liquid calibrations), the uncertainty of the standard, the inlet transmission and an ozone interference correction was about $12-13 \%$. During the campaign the inlet transmission was determined twice by adding the gas-phase standard at the top of the inlet line. Comparison of two calibrations directly in front of the analyzer yielded a transmission that decreased from $67 \%$ at the beginning of the campaign to $57 \%$ towards the end. The instrument has also been used (in combination with a constant pressure inlet) for airborne measurement of $\mathrm{H}_{2} \mathrm{O}_{2}$ in the free troposphere over the rainforest in South America (Stickler et al., 2007) and over Europe (Klippel et al., 2011).
A discussion of uncertainties of the MHP measurements can be based on extreme cases (all ROOH is MHP vs. no MHP at all). The model analysis on $\mathrm{RO}_{x}$ radicals presented in Hosaynali Beygi et al. (2011) indicates that no other organic peroxy radicals other than $\mathrm{CH}_{3} \mathrm{O}_{2}$ are expected in the very clean marine boundary layer, indicating that MHP dominates the $\mathrm{ROOH}$ signal of the analyzer. A sampling efficiency of $60 \%$ for MHP is a reasonable assumption. The efficiency cannot be higher than that for $\mathrm{H}_{2} \mathrm{O}_{2}(95 \%)$ and is unlikely smaller than $30 \%$, thus yielding an uncertainty of $\pm 30 \%$. One should also mention that catalase reacts to some extent with MHP. The commercial analyzer (AERO-Laser, Model AL 2001CA) that has been used is based on the original design of Lazarus et al. (1986). As discussed in this paper, the effect of catalase destruction on MHP is estimated to be about $3 \%$, an order of magnitude less than the uncertainty due to the sampling issue discussed above.

The detection limit is determined from the reproducibility of the zero-air measurements in both channels of the analyzer and strictly applies to the $\mathrm{H}_{2} \mathrm{O}_{2}$ channel. A rough estimate for MHP can be gained by multiplying with the sampling efficiency of 0.6 , yielding a value of 40 pptv.

The instrument used to measure ozone (together with NO and $\mathrm{NO}_{2}$ ) is a high-resolution ( $\left.1 \mathrm{~s}\right)$ and highly sensitive threechannel chemiluminescence detector (CLD, ECO Physics CLD 790 SR, Duernten, Switzerland). The instrument and its performance characteristics during this campaign have been described in detail in a previous publication on the $\mathrm{NO}_{x} / \mathrm{O}_{3}$ photostationary state by Hosaynali Beygi et al. (2011). The total uncertainty for the $\mathrm{O}_{3}$ channel was determined from the $2 \sigma$ deviation of the in-field calibrations (ozone calibrator model TE49C, Thermo Instruments, Germany) and the accuracy of the standard, estimated at $1 \%$ (Hosaynali Beygi et al., 2011).

\subsection{Atmospheric chemistry model EMAC}

Simulations of trace gas mixing ratios along the ship cruise were performed using the EMAC global circulation model (Jöckel et al., 2010). EMAC uses the Modular Earth Submodel System (MESSy; Jöckel et al., 2005) to link multiinstitutional submodels describing atmospheric processes 


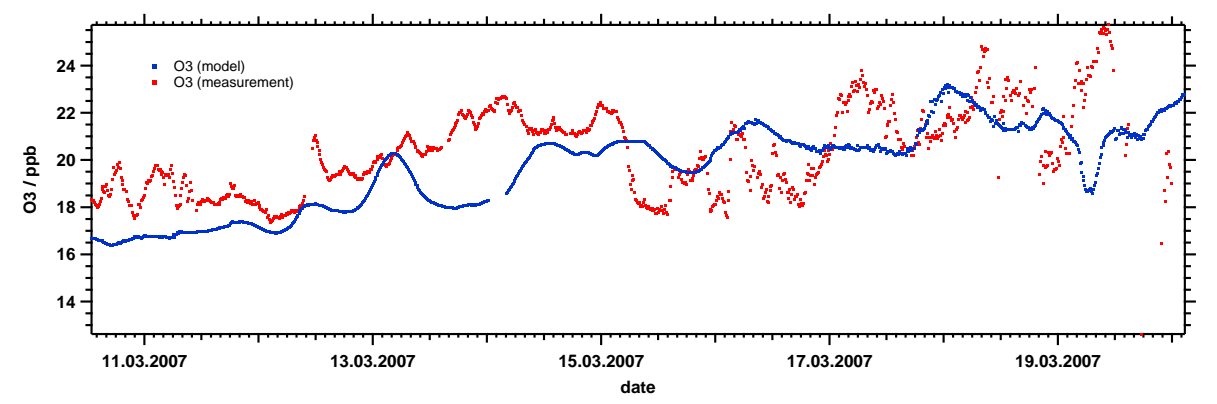

Figure 3. Time series of observed (red) and simulated (blue) ozone mixing ratios.

interacting with oceans, land and human influences. For this study EMAC was applied in the T42L90MA resolution $\left(2.8^{\circ} \times 2.8^{\circ}\right.$ resolution in latitude and longitude, 90 vertical levels up to $0.01 \mathrm{hPa}$ ), using results from the lowest model level $(\sim 30 \mathrm{~m})$ for comparison with measurements. The model was sampled (spatial bilinearly interpolated) along the ship track at every time step (i.e., $12 \mathrm{~min}$ ) using the SD4 submodel (Jöckel et al., 2010), without any temporal interpolation. The meteorology was nudged to the operational ECMWF analysis. Tropospheric gas-phase and heterogeneous chemistry was calculated with the submodel MECCA (Module Efficiently Calculating the Chemistry of the Atmosphere; Sander et al., 2005), aqueous-phase chemistry in cloud droplets and wet scavenging with the submodel SCAV (Tost et al., 2006) and primary emissions and dry deposition of trace gases and aerosols with the submodels ONLEM, OFFLEM, TNUDGE and DRYDEP (Kerkweg et al., 2006a, b). Previous results of a model comparison with airborne $\mathrm{H}_{2} \mathrm{O}_{2}$ measurements in the free troposphere have been discussed in Klippel et al. (2011).

\section{Results and discussion}

\subsection{Data processing}

For the present analysis the original observations were averaged over $12 \mathrm{~min}$ time intervals to be coherent with the model output time stepping. The timescale used is UTC, thus leading to deviations from solar noon of $-80 \mathrm{~min}$ for the most westerly point $\left(20^{\circ} \mathrm{W}\right)$ of the ship track to $140 \mathrm{~min}$ for the most easterly $\left(35^{\circ} \mathrm{E}\right)$. Unfortunately due to the prevailing westerly winds the instruments often measured air polluted by the ship exhausts, notably when the wind was from the sector between 55 and $275^{\circ}$. This stack air contained very high concentrations of NO (up to $200 \mathrm{ppbv}$ in individual plumes), leading to complete titration of $\mathrm{O}_{3}$, while $\mathrm{H}_{2} \mathrm{O}_{2}$ was not affected at all on the short timescales involved, as has been observed previously (Weller et al., 2000). In total $53 \%$ of the observations were effected by stack emissions. Therefore we used $\mathrm{O}_{x}\left(\mathrm{O}_{3}+\mathrm{NO}_{2}\right)$ for the experimental data to deduce the original $\mathrm{O}_{3}$ concentration that would have oc- curred without $\mathrm{NO}$ titration to $\mathrm{NO}_{2}$. In general, the difference between $\mathrm{O}_{x}$ and $\mathrm{O}_{3}$ is marginal due to the very low $\mathrm{NO}_{x}$ mixing ratios of less than 20 pptv in the remote marine boundary layer over the South Atlantic and less than 200 pptv east of southern Africa (Hosaynali Beygi et al., 2011). Thus the error in $\mathrm{O}_{3}$ using $\mathrm{O}_{x}$ in all cases is smaller than $2 \%$. From the model only the original $\mathrm{O}_{3}$ data are used.

\subsection{Distribution of measured and simulated trace gases}

Figure 3 shows the time series for measured and simulated ozone mixing ratios. Observed $\mathrm{O}_{3}$ varies between 17 and $25 \mathrm{ppbv}$, with lower values in the western South Atlantic and higher values closer to Africa. The model qualitatively reproduces this gradient with a slight tendency to underestimate $\mathrm{O}_{3}$ mixing ratios during the first part of the cruise (10-14 March) and a slight overestimation between 15 and 17 March. During the last part of the cruise after 17 March both model and observations agree quite well. Overall, the mean observed and simulated $\mathrm{O}_{3}$ are $20.3 \pm 1.8$ and $19.7 \pm 2$ ppbv, respectively. A least-squares fit between simulated ( $y$ axis) and observed ( $x$ axis) ozone yields a slope of $0.98 \pm 0.01$ and an offset of $-0.43 \pm 0.21 \mathrm{ppbv}$. The regression coefficient $R^{2}$ is rather low (0.2). Taking into account that observed $\mathrm{O}_{x}$ measurements are affected by background $\mathrm{NO}_{2}$, the agreement between observations and model results is quite satisfactory. Observations and model results are in good agreement with observations by Helmig et al. (2012) during the GasEx 2008 cruise in the South Atlantic at $50^{\circ} \mathrm{S}$ between 65 and $35^{\circ} \mathrm{W}$ in March 2008; they reported an average $\mathrm{O}_{3}$ mixing ratio of $18.3 \mathrm{ppbv}$. Similar $\mathrm{O}_{3}$ mixing ratios on the order of $20 \mathrm{ppbv}$ were also observed over the South Atlantic, south of $40^{\circ} \mathrm{S}$, during three Polarstern cruises in November 1990 (Slemr and Tremmel, 1994), October-November 1994 (Junkermann and Stockwell, 1999) and March 1999 (Jacobi and Schrems, 1999). As discussed in Lelieveld et al. (2004), seasonal variations of $\mathrm{O}_{3}$ in the latitude band between 40 and $60^{\circ} \mathrm{S}$ are rather small, with slightly lower values in austral summer. For the period between 1977 and 2002 the calculated $\mathrm{O}_{3}$ trend for this latitude band is $0.17 \pm 0.08$ ppbvyear $^{-1}$ (Lelieveld et al., 2004), indicating a moderate increase of approximately 


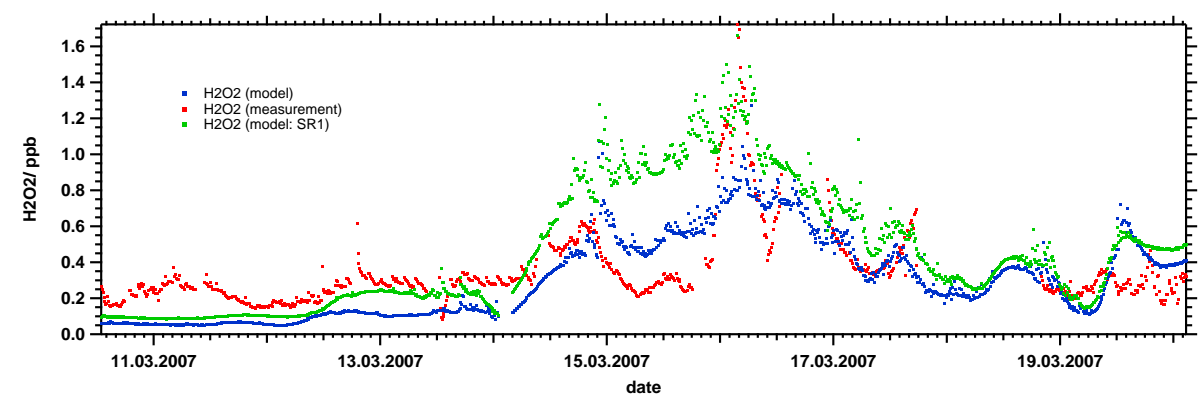

Figure 4. Time series of observed (red) and simulated (blue) hydrogen peroxide mixing ratios. In green a sensitivity simulation (SR1) of the model is shown with reduced dry deposition velocity (see text for details).

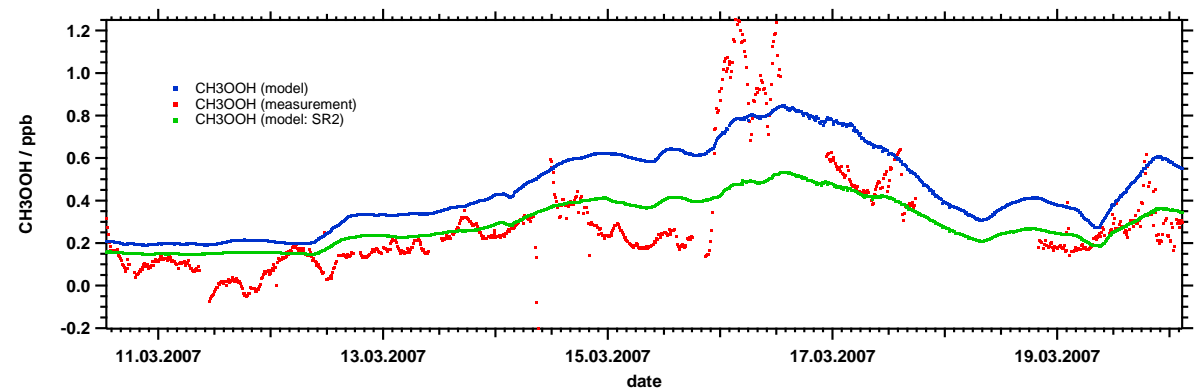

Figure 5. Time series of observed (red) and simulated (blue) methylhydroperoxide mixing ratios. The green line shows a sensitivity simulation (SR2) including the reaction of $\mathrm{CH}_{3} \mathrm{O}_{2}$ with $\mathrm{OH}$ (see text for details).

1 ppbv between 2002 and 2007. Based on the limited number of observations during OOMPH a conclusion about the continuation of this trend is not possible.

Time series of measured and simulated $\mathrm{H}_{2} \mathrm{O}_{2}$ are shown in Fig. 4. During the first part of the cruise (10 to 14 March) observed $\mathrm{H}_{2} \mathrm{O}_{2}$ mixing ratios indicate small variability at levels between 200 and 300 pptv. During this period the model significantly underestimates observed $\mathrm{H}_{2} \mathrm{O}_{2}$, by more than a factor of 2. After 14 March in the eastern part of the South Atlantic, $\mathrm{H}_{2} \mathrm{O}_{2}$ mixing ratios tend to increase both in the observations and the model simulations, with the model overestimating observations during the first part, in particular on 15 March, while later on measurements and model results agree quite well. A period of relatively high $\mathrm{H}_{2} \mathrm{O}_{2}$ (in excess of $1 \mathrm{ppbv}$ ) was observed and simulated after midnight on 16 March, southwest of the African coast (see Fig. 1). On average observed and simulated $\mathrm{H}_{2} \mathrm{O}_{2}$ were $350 \pm 220$ and $310 \pm 240$ pptv, respectively. Slope and intercept of a least-squares regression analysis are $2.04 \pm 0.04$ and $-0.27 \pm 0.04 \mathrm{ppbv}$, respectively. The regression coefficient $R^{2}$ is 0.46 . The imperfect agreement here between model results and observations is due to the rather limited dynamical range of mixing ratios and the strong offset during the first part of the cruise. This is also the case for $\mathrm{O}_{3}$. As can be deduced from the time series (Fig. 4), the model tends to reproduce trace gas levels over the South Atlantic. The measured $\mathrm{H}_{2} \mathrm{O}_{2}$ mixing ratios are comparable to previously reported observations south of $35^{\circ} \mathrm{S}$ in the Atlantic lower troposphere, being approximately 200-300 pptv (Slemr and Tremmel, 1994; Junkerman and Stockwell, 1999; Weller et al., 2000).

Observations of $\mathrm{CH}_{3} \mathrm{OOH}$ mixing ratios are shown in the time series in Fig. 5 along with EMAC simulations. The temporal evolution is similar to $\mathrm{H}_{2} \mathrm{O}_{2}$, with low values (less than $200 \mathrm{pptv}$ ) during the first part of the cruise, a strong mixing ratio increase starting at midnight of 16 March and lower concentrations afterwards. The relative change is reproduced by the model, with a general tendency to overestimate $\mathrm{CH}_{3} \mathrm{OOH}$ mixing ratios except during the period when the high peak was encountered on 16 March. Average measured $\mathrm{CH}_{3} \mathrm{OOH}$ mixing ratios are $280 \pm 250 \mathrm{pptv}$, while the model calculates a mean value of $450 \pm 190$ pptv. The offset between model and observations is clearly shown in the least-squares regression analysis that yields an intercept at $0.18 \pm 0.05 \mathrm{ppbv}$ and a slope of $0.37 \pm 0.12$ at an $R^{2}$ of 0.6. In general the observed mixing ratios are in good agreement with reported levels in the literature (Slemr and Tremmel, 1994; Junkerman and Stockwell, 1999; Weller et al., 2000).

With the exception of the mixing ratio peaks on 16 March, the variability of $\mathrm{O}_{3}, \mathrm{H}_{2} \mathrm{O}_{2}$ and $\mathrm{CH}_{3} \mathrm{OOH}$ is small across the South Atlantic basin between South America and southern Africa. The slightly northward orientation of the ship track results in a steady increase in temperature and photolysis rates (Hosaynali Beygi et al., 2011), leading to increasing 


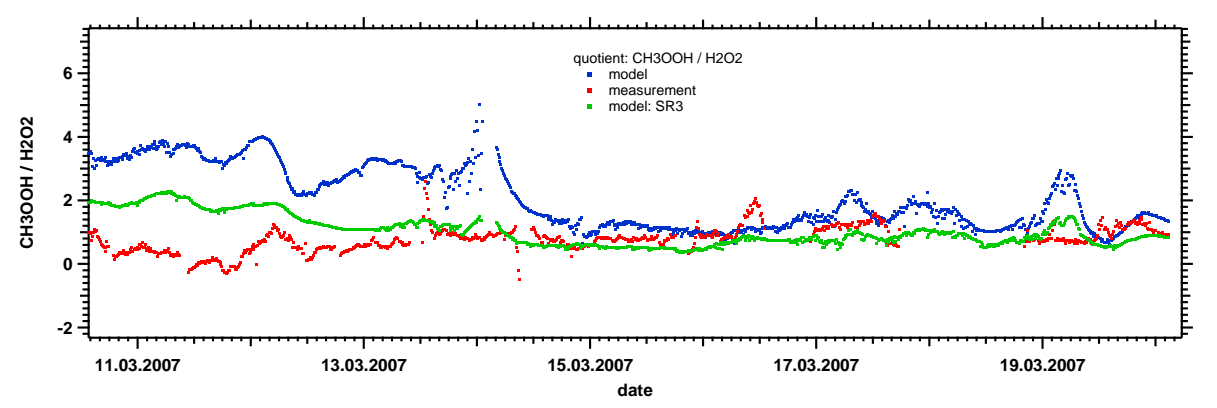

Figure 6. Simulated (blue) and observed (red) $\mathrm{CH}_{3} \mathrm{OOH}-$ to- $\mathrm{H}_{2} \mathrm{O}_{2}$ ratio. The green line shows a sensitivity simulation (SR3) including reduced $\mathrm{H}_{2} \mathrm{O}_{2}$ dry deposition velocity and the reaction of $\mathrm{CH}_{3} \mathrm{O}_{2}$ with $\mathrm{OH}$ (see text for details).

photochemical activity that is likely responsible for the slight increase of the mixing ratios of the three species from the southwestern to the northeastern part of the South Atlantic. As shown in a backward trajectory analysis presented in Hosaynali Beygi et al. (2011), the air mass origin did not change throughout the cruise. All air masses encountered during the cruise originated in the western Antarctic Peninsula during the preceding week and had not been in contact with land surfaces for at least 5 days.

\subsection{Discussion}

Based on $\mathrm{H}_{2} \mathrm{O}_{2}$ mixing ratios and the comparison between observations and model results, one can differentiate three different periods in Fig. 4: From 10 to 14 March the model significantly underestimates the $\mathrm{H}_{2} \mathrm{O}_{2}$ mixing ratios, while the agreement is much better during the final phase of the campaign (after 17 March). In between these two periods $\mathrm{H}_{2} \mathrm{O}_{2}$ mixing ratios show a strong increase to well above 1 ppbv that is well reproduced by the model.

Similar behavior is also observed for ozone (Fig. 3). The model also tends to underestimate $\mathrm{O}_{3}$ mixing ratios during the early phase of the campaign, while the agreement is much better in the second half of the campaign. On the other hand, the $\mathrm{CH}_{3} \mathrm{OOH}$ mixing ratios are almost always overestimated by the model (Fig. 5). Considering the ratio between $\mathrm{CH}_{3} \mathrm{OOH}$ and $\mathrm{H}_{2} \mathrm{O}_{2}$, there is an even stronger discrepancy (Fig. 6). Over the whole campaign, the observed ratio varies between 0.5 and 1 with a mean value and standard deviation of $0.8 \pm 1.1$, while the model predicts a time dependent ratio between 2 and 4 during the first half of the campaign and lower values, in good agreement with the observations, during the second half of the campaign. Hence one problem seems to be that the model underestimates $\mathrm{H}_{2} \mathrm{O}_{2}$ during the early phase of the campaign, due to either an underestimation of the $\mathrm{H}_{2} \mathrm{O}_{2}$ production or an overestimation of the sinks. Gas-phase $\mathrm{H}_{2} \mathrm{O}_{2}$ in the marine boundary layers stems from the recombination of two $\mathrm{HO}_{2}$ radicals. As shown by Hosaynali Beygi et al. (2011), EMAC reproduces observed $\mathrm{HO}_{2}$ levels (observations are shown in Fig. 10 and model results in Fig. 11 of Hosay- nali Beygi et al., 2011) during the whole campaign and indicates similar levels for $\mathrm{HO}_{2}$ and $\mathrm{CH}_{3} \mathrm{O}_{2}$, the precursors of $\mathrm{CH}_{3} \mathrm{OOH}$. A scatterplot (not shown) and a regression analysis indicate that the model tends to overestimate observed $\mathrm{HO}_{2}$ by approximately $20 \%$ throughout the campaign $\left(\mathrm{HO}_{2}(\mathrm{obs})=(0.786 \pm 0.004) \times \mathrm{HO}_{2}(\right.$ model $)-(0.44 \pm 0.03)$; $\left.R^{2}=0.87\right)$. The total uncertainty of the $\mathrm{HO}_{2}$ measurements is $\pm 35 \%(2 \sigma)$ (Hosaynali Beygi et al., 2011), indicating that $\mathrm{HO}_{2}$ observations and simulations agree within the uncertainties of the observations (a total uncertainty for the simulations is not available and not easy to derive). Thus the simulation tends to overestimate the $\mathrm{H}_{2} \mathrm{O}_{2}$ source by about $40 \%$, assuming that $\mathrm{HO}_{2}$ reacts only with $\mathrm{HO}_{2}$ and reactions with $\mathrm{NO}$ are negligible, which is justified by the very low $\mathrm{NO}_{x}$ levels of less than 20 pptv in both observations and simulations. Given that the precursor levels are slightly overestimated by EMAC, it is very unlikely that an underestimation of the peroxide production is responsible for the $\mathrm{H}_{2} \mathrm{O}_{2}$ underestimation during the first half of the campaign. This indicates that the discrepancies are due to an overestimation of the $\mathrm{H}_{2} \mathrm{O}_{2}$ sinks in the model during this period. Photochemical sinks (reaction with $\mathrm{OH}$ and $\mathrm{H}_{2} \mathrm{O}_{2}$ photolysis) are also unlikely causes, since the model also reproduces $\mathrm{OH}$ concentrations (Hoseynali Beygi et al., 2011) and radiation intensities (not shown). The model simulations of the photochemical $\mathrm{H}_{2} \mathrm{O}_{2}$ sinks indicate that during noon the maximum contribution of $\mathrm{H}_{2} \mathrm{O}_{2}$ photolysis and reaction with $\mathrm{OH}$ varies between $2 \%$ (11 March) and a maximum of $12 \%$ (19 March). Hence the influence of the photochemical sinks on the $\mathrm{H}_{2} \mathrm{O}_{2}$ mixing ratio is marginal (setting both sinks to 0 would increase the simulated $\mathrm{H}_{2} \mathrm{O}_{2}$ mixing ratios by ca. $10 \%$ ). Other sinks of $\mathrm{H}_{2} \mathrm{O}_{2}$, in particular $\mathrm{H}_{2} \mathrm{O}_{2}$ uptake on aerosols, were not considered in the model simulation and thus cannot be responsible for the underestimation of the $\mathrm{H}_{2} \mathrm{O}_{2}$ mixing ratio in the simulations. The same is true for $\mathrm{HO}_{2}$ loss on aerosols, which was also not considered in the model simulation.

This leaves physical removal processes, such as rainout and dry deposition to the surface, as the most likely causes. Although the model predicts some rain events, they are not particularly extensive during the first phase, 
when the problems occur. A striking observation is that the wind speeds are significantly higher during the first part of the campaign, being well above $10 \mathrm{~ms}^{-1}$ up to 15 March (Fig. 1), while they are generally lower in the second half of the campaign. The dry deposition in EMAC (Kerkweg et al., 2006a, b) is based on the dry deposition scheme of Ganzeveld and Lelieveld (1995) and Ganzeveld et al. (1998) partly following Wesley (1989). For highly soluble species like $\mathrm{H}_{2} \mathrm{O}_{2}$ the ocean surface resistance is assumed to be negligible, and the deposition velocity strongly depends on the wind speed, which determines the transfer velocity to the ocean surface. For less soluble species like $\mathrm{O}_{3}$ and MHP the dry deposition velocity is dominated by a nonzero ocean uptake resistance (Ganzeveld and Lelieveld, 1995). The deposition velocity calculated by the model for $\mathrm{O}_{3}$ hardly depends on the wind speed, being as small as $\sim 0.05 \mathrm{~cm} \mathrm{~s}^{-1}$, indicating that the deposition loss is limited by the ocean uptake resistance. On the other hand, the $\mathrm{H}_{2} \mathrm{O}_{2}$ deposition velocity is a strong function of wind speed, linearly increasing from $\sim 0.5 \mathrm{~cm} \mathrm{~s}^{-1}$ at a wind speed of $5 \mathrm{~m} \mathrm{~s}^{-1}$ to about $1.8 \mathrm{~cm} \mathrm{~s}^{-1}$ at $10 \mathrm{~m} \mathrm{~s}^{-1}$. This indicates that the deposition loss for this highly soluble species is limited by the transfer velocity to the ocean surface. These values are in good agreement with those derived from airborne measurements in the marine boundary layer over the Atlantic Ocean off the coast of South America during GABRIEL 2005 (Stickler et al., 2007). Based on $\mathrm{H}_{2} \mathrm{O}_{2}$ observations and an assumed rate of entrainment from the free troposphere, Stickler et al. (2007) estimated an $\mathrm{H}_{2} \mathrm{O}_{2}$ deposition velocity of $1.3 \mathrm{~cm} \mathrm{~s}^{-1}$ (range $<0.1$ to $>1.8 \mathrm{~cm} \mathrm{~s}^{-1}$, depending on the assumptions for the entrainment rate) at a wind speed of $6 \mathrm{~m} \mathrm{~s}^{-1}$. The single-column model used in the study of Stickler et al. (2007) yielded a maximum deposition velocity of $0.5 \mathrm{~cm} \mathrm{~s}^{-1}$ at that wind speed, which is in good agreement with the EMAC results. Accordingly, due to the absence of low clouds and precipitation during the campaign (for the considered period), dry deposition is the dominant loss process for $\mathrm{H}_{2} \mathrm{O}_{2}$ in the model, even during the day. During the night dry deposition is the only loss mechanism, as photochemical destruction ceases. The model indicates that during daytime the contribution of dry deposition to total $\mathrm{H}_{2} \mathrm{O}_{2}$ loss varies between $98 \%$ (noon values) during the first part of the campaign (11 to 14 March) and about $90 \%$ during the second half (after 15 March), due to a combination of decreasing dry deposition loss due to decreasing wind speeds and a simultaneous increase by enhanced photochemical activity at lower latitudes. We performed a sensitivity study (SR1) with EMAC, limiting the maximum wind used in the deposition calculation to $5 \mathrm{~m} \mathrm{~s}^{-1}$, resulting in a maximum deposition velocity of $\mathrm{H}_{2} \mathrm{O}_{2}$ of around $0.6 \mathrm{~cm} \mathrm{~s}^{-1}$. The green line in Fig. 4 shows that this leads to an increase in simulated $\mathrm{H}_{2} \mathrm{O}_{2}$ mixing ratios by approximately $50 \%$ (mean calculated mixing ratio: $460 \pm 350 \mathrm{pptv}$ ). It should be mentioned that globally this effect is strongest in the marine boundary layer in regions of high wind speed, notably in the latitude band between 40 and $60^{\circ}$ of the storm tracks in both hemispheres.
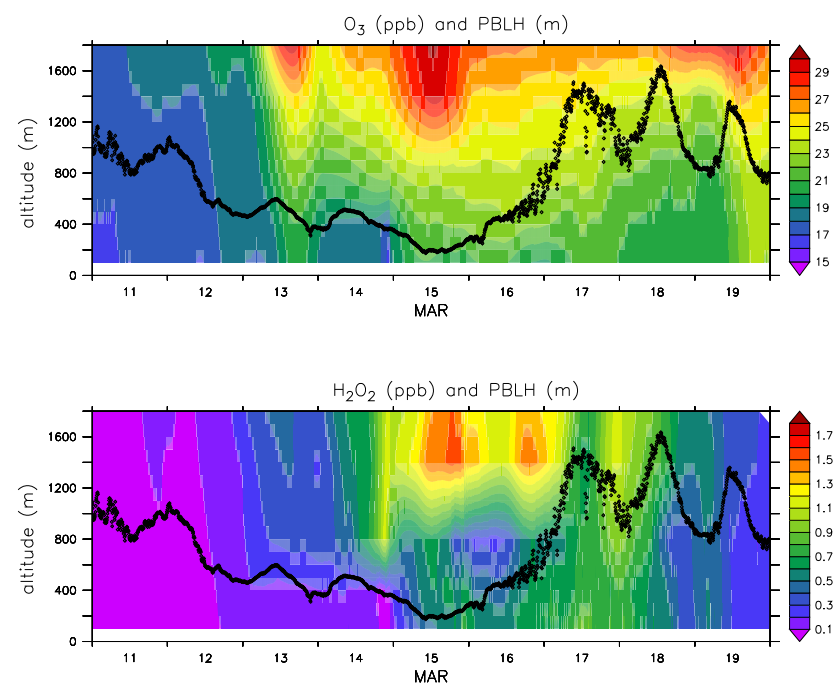

Figure 7. EMAC simulation of $\mathrm{O}_{3}$ (top) and $\mathrm{H}_{2} \mathrm{O}_{2}$ (bottom) vertical profiles versus time. Superimposed is the height of the planetary boundary layer. The increase in boundary layer height in the night from 15 to 16 March is associated with an increase in peroxide mixing ratios.

Outside of these regions the effect is much smaller and leads to increases in the $\mathrm{H}_{2} \mathrm{O}_{2}$ mixing of less than $20 \%$. Thus it appears that the differences between model simulations and $\mathrm{H}_{2} \mathrm{O}_{2}$ observations are due to a model overestimation of dry deposition to the ocean at high wind speed. This hardly affects $\mathrm{CH}_{3} \mathrm{OOH}$ and $\mathrm{O}_{3}$, whose deposition loss is limited by their solubility and thus independent of wind speed, while $\mathrm{H}_{2} \mathrm{O}_{2}$ is much more strongly affected. The importance of the deposition parameterization, being a critical process in the simulation of $\mathrm{H}_{2} \mathrm{O}_{2}$ in the lower troposphere, was also emphasized by Chang et al. (2004), who performed sensitivity studies with a single-column model to simulate observations from PEM-Tropics B.

Another interesting feature of the $\mathrm{H}_{2} \mathrm{O}_{2}$ time series in Fig. 4 is the strong increase of $\mathrm{H}_{2} \mathrm{O}_{2}$ in the night from 15 to 16 March. Shortly before midnight the $\mathrm{H}_{2} \mathrm{O}_{2}$ mixing ratio increases strongly from $\sim 0.7$ up to about $1.5 \mathrm{ppbv}$, and decreasing to the previous mixing ratios before noon on 16 March. The sudden increase occurs together with a similar increase in $\mathrm{CH}_{3} \mathrm{OOH}$ (Fig. 5), which is qualitatively reproduced by EMAC. Since the sudden increase in $\mathrm{H}_{2} \mathrm{O}_{2}$ and $\mathrm{CH}_{3} \mathrm{OOH}$ occurs during nighttime, a photochemical source can be excluded. During this phase of the campaign the ship was south of the southern tip of Africa. One explanation for the sudden increase could be a change in air mass origin. Heikes et al. (1996) observed a significant increase of marine boundary layer $\mathrm{H}_{2} \mathrm{O}_{2}$ mixing ratios north of $20^{\circ} \mathrm{N}$ in continental outflow. Trajectory calculations for the OOMPH campaign were presented in the supplements to the paper by Hosaynali Beygi et al. (2011). They indicate, however, no 
change in air mass origin during the period between 15 and 17 March, so this option can be dismissed.

Due to the dry deposition close to the ocean surface, both $\mathrm{H}_{2} \mathrm{O}_{2}$ and $\mathrm{CH}_{3} \mathrm{OOH}$ are expected to exhibit an increase in mixing ratios with height. Aircraft observations over the ocean indeed show maxima of both species above the marine boundary layer (Heikes et al., 1996; O'Sullivan et al., 1999, 2004; Stickler et al., 2007). Thus transport from above the boundary layer can be a source of $\mathrm{H}_{2} \mathrm{O}_{2}$ and $\mathrm{CH}_{3} \mathrm{OOH}$ for the marine boundary layer. Observations of the boundary layer height were not made during the OOMPH campaign; thus we have to rely on model results. The curtain plot in Fig. 7 shows a time series of the vertical profiles for $\mathrm{O}_{3}$ (upper panel) and $\mathrm{H}_{2} \mathrm{O}_{2}$ (lower panel). Superimposed is the temporal evolution of the boundary layer height calculated by EMAC. Note that the diurnal variation of the boundary layer height during 17-19 March is related to the proximity to the African continent. Due to the limited resolution of the model the data points here are interpolated between an oceanic and a continental grid cell, leading to a diurnal evolution of the boundary layer height that resembles that of a continental boundary layer instead of the marine boundary layer. Shortly before the event the simulation indicates a very shallow boundary layer $(\sim 200 \mathrm{~m})$ that starts to increase around midnight on 16 March. Hence the increase in $\mathrm{H}_{2} \mathrm{O}_{2}$ is related to an increase in boundary layer height and to downward mixing of air masses that have not been affected by deposition and thus having higher mixing ratios of peroxides. Thus it seems that nighttime transport of free-tropospheric air into the marine boundary layer is responsible for the concentration increase during the period from 15 to 16 March. This vertical redistribution process should also affect other species with a positive altitude gradient, in particular ozone. Model profiles indicate that the mixing ratio gradient for $\mathrm{O}_{3}$ is much smaller than for $\mathrm{H}_{2} \mathrm{O}_{2}$ (upper panel in Fig. 7). This is consistent with the moderate change in $\mathrm{O}_{3}$ mixing ratios during this event.

Finally, the difference in simulated and observed absolute mixing ratios of $\mathrm{CH}_{3} \mathrm{OOH}$ needs to be addressed. Figure 5 indicates that, although the model reproduces the relative changes quite well, the absolute values are off by a factor of about 2 , with the model being consistently higher. The relative difference is higher in the beginning and lower towards the end of the campaign, but the absolute difference remains about 200 pptv. There are several potential explanations for this discrepancy. First, as mentioned in Sect. 2.2, $\mathrm{CH}_{3} \mathrm{OOH}$ was not directly measured but inferred from the $\mathrm{ROOH}$ signal, assuming that $\mathrm{CH}_{3} \mathrm{OOH}$ is the only organic hydroperoxide and that the sampling efficiency can be calculated according to Lee et al. (2000). An experimental verification of the sampling efficiency was not performed (contrary to $\mathrm{H}_{2} \mathrm{O}_{2}$ ) since no $\mathrm{CH}_{3} \mathrm{OOH}$ gas-phase source was available. If the actual sampling efficiency was lower than the calculated $60 \%$, this could close the gap between observations and model results. Additionally, the sampling efficiency would have to be lower at the beginning of the campaign and higher later on, since a simple multiplication by a factor cannot account for the rather constant absolute difference over the campaign. Therefore, although an error in the sampling efficiency cannot be excluded, it is unlikely the only source of the discrepancy between model and observations.

As discussed above, Hosaynali Beygi et al. (2011) demonstrated that EMAC very well reproduces the $\mathrm{HO}_{2}$ measurements made during the OOMPH cruise. Since the precursor for $\mathrm{H}_{2} \mathrm{O}_{2}$ is simulated correctly by the model, one can assume that the source strength for $\mathrm{H}_{2} \mathrm{O}_{2}$ is correctly simulated. The model predicts $\mathrm{CH}_{3} \mathrm{O}_{2}$ concentrations that are similar to $\mathrm{HO}_{2}$, but unfortunately measurements of $\mathrm{CH}_{3} \mathrm{O}_{2}$ were not made. Thus it is not possible to validate the modelpredicted precursor concentrations for $\mathrm{CH}_{3} \mathrm{OOH}$. But as discussed in Hosaynali Beygi et al. (2011) the simulated $\mathrm{CH}_{3} \mathrm{O}_{2}$ levels are quite realistic. Recently Fittschen et al. (2014) posited that the reaction of $\mathrm{CH}_{3} \mathrm{O}_{2}$ with $\mathrm{OH}$ radicals at low $\mathrm{NO}_{x}$ concentrations can be a significant sink of methylperoxy radicals and thus could reduce $\mathrm{CH}_{3} \mathrm{OOH}$ formation. In a sensitivity study (SR2) this reaction was included in the chemistry code of EMAC (Bossolasco et al., 2014). Additionally, we considered that in addition to $\mathrm{CH}_{3} \mathrm{OOH}$ the reaction of $\mathrm{CH}_{3} \mathrm{O}_{2}$ with $\mathrm{HO}_{2}$ also produces $\mathrm{HCHO}$ to some extent (Ayers et al., 1997). The green line in Fig. 6 indicates that including these additional reaction pathways reduces the mixing ratio of $\mathrm{CH}_{3} \mathrm{O}_{2}$ in the marine boundary layer of the South Atlantic by about $30 \%$, yielding an average mixing ratio of $300 \pm 110 \mathrm{pptv}$ compared to the observed $180 \pm 50 \mathrm{pptv}$. It seems that the missing reaction between $\mathrm{CH}_{3} \mathrm{O}_{2}$ and $\mathrm{OH}$ is responsible for a largest part of the $\mathrm{CH}_{3} \mathrm{OOH}$ overestimation by the model, in particular during the second half of the cruise when $\mathrm{OH}$ concentrations are high. In general, the contribution of this reaction increases with increasing $\mathrm{OH}$ concentration, which leads globally to a maximum impact in the tropical lower troposphere over the Pacific and Indian oceans. The contribution of the HCHO channel in the reaction of $\mathrm{CH}_{3} \mathrm{O}_{2}$ with $\mathrm{HO}_{2}$ is rather constant, with a branching ratio of about $10 \%$. Nevertheless, due to the uncertainties in both measurements and modeling the explanation for the difference in $\mathrm{CH}_{3} \mathrm{OOH}$ simulation vs. observations remains ambiguous.

By combining both the reduced $\mathrm{H}_{2} \mathrm{O}_{2}$ deposition velocity and the reduced $\mathrm{CH}_{3} \mathrm{OOH}$ source due to the competing reaction of $\mathrm{CH}_{3} \mathrm{O}_{2}$ with $\mathrm{OH}$ in an additional sensitivity simulation (SR3) the simulated $\mathrm{CH}_{3} \mathrm{OOH} / \mathrm{H}_{2} \mathrm{O}_{2}$ ratio is reduced to a mean value of $1.01 \pm 1.06$ (green line in Fig. 6), much closer to the observed value $(0.8 \pm 1.1)$.

Note that an underestimation of entrainment from the free troposphere would also explain the underestimation of the $\mathrm{H}_{2} \mathrm{O}_{2}$ (and $\mathrm{O}_{3}$ ) mixing ratios during the first phase of the campaign. However, this leads to an inconsistency with the MHP data, which would be affected by the same transport. Similar to $\mathrm{H}_{2} \mathrm{O}_{2}$ and $\mathrm{O}_{3}$, MHP mixing ratios increase with altitude and show a maximum above the boundary layer 
(Stickler et al., 2007; Klippel et al., 2011). Thus one would expect that a transport limitation from the free troposphere in the simulations would also produce an underestimation of the simulated MHP concentrations in the MBL, but the opposite is the case; actually the model significantly overestimates MHP. Therefore, we conclude that different processes are responsible for the temporal underestimation of $\mathrm{H}_{2} \mathrm{O}_{2}$ (during the first part of the campaign) and the time-independent overestimation of MHP, as most clearly corroborated in the time series of the ratio of these two species in Fig. 6.

\section{Summary and conclusions}

Hydrogen peroxide, MHP and ozone were measured in the marine boundary layer over the South Atlantic Ocean during the austral summer in 2007. Observed mixing ratios are consistent with values reported in the literature. Simulations with the atmospheric chemistry model EMAC indicate that it qualitatively reproduces the observations very well. It also qualitatively reproduces the downward mixing of high concentrations of $\mathrm{H}_{2} \mathrm{O}_{2}$ and $\mathrm{CH}_{3} \mathrm{OOH}$ during a nighttime increase in boundary layer height south of the African continent. Quantitatively, the model tends to underestimate $\mathrm{H}_{2} \mathrm{O}_{2}$ mixing ratios during the first part of the cruise. During this part we experienced very high wind speeds, in excess of $15 \mathrm{~m} \mathrm{~s}^{-1}$. Later on during the cruise much lower wind speeds were encountered for which the model accurately reproduces observed $\mathrm{H}_{2} \mathrm{O}_{2}$ mixing ratios. A similar tendency has been observed for ozone. The most likely reason for the discrepancy is that the model parameterization of trace gas deposition to the ocean surface tends to overestimate the dry deposition loss of the soluble and reactive $\mathrm{H}_{2} \mathrm{O}_{2}$ at high wind speeds. This was confirmed by a model sensitivity study with limited (at $5 \mathrm{~cm} \mathrm{~s}^{-1}$ ) deposition velocity. MHP, which is less soluble and reactive, is not as greatly affected by dry deposition, although EMAC significantly overestimates its mixing ratio. This overestimation is rather constant over the campaign and indicates an offset of approximately $200 \mathrm{pptv}$. The reasons for this discrepancy are not easy to identify, since the measurements provide less stringent constraints than for $\mathrm{H}_{2} \mathrm{O}_{2}$. MHP was estimated from a total ROOH signal, assuming MHP being the only ROOH component and a sampling efficiency of $60 \%$ compared to $\mathrm{H}_{2} \mathrm{O}_{2}$. Fittschen et al. (2014) recently suggested that a competing reaction of the $\mathrm{CH}_{3} \mathrm{O}_{2}$ radicals with $\mathrm{OH}$ can significantly diminish the source of MHP in the marine boundary layer, in particular at the low $\mathrm{NO}_{x}$ concentrations observed during OOMPH. A sensitivity study with EMAC indicates that this reaction reduces the $\mathrm{CH}_{3} \mathrm{O}_{2}$ mixing ratio by about $30 \%$, increasing with decreasing latitude due to the meridional gradient in $\mathrm{OH}$ radical concentrations. Although this is a significant change, bringing $\mathrm{CH}_{3} \mathrm{OOH}$ closer to observations, it appears to be insufficient to fully remove the discrepancy between simulated and observed $\mathrm{CH}_{3} \mathrm{OOH}$ mixing ratios during OOMPH.
Acknowledgements. We are grateful to the OOMPH campaign (MD160) team: U. Parchatka, C. Gurk, R. Königstedt, H. D. Harder, M. Martinez, D. Kubistin, M. Rudolf, Z. Hoysaynali Beygi and J. Williams. We also thank $\mathrm{H}$. Wernli for providing back trajectory data. The OOMPH project was funded under the EU Sixth Framework Programme (018419).

The article processing charges for this open-access publication were covered by the Max Planck Society.

Edited by: R. Holzinger

\section{References}

Ayers, G. P., Gillet, R. W., Granek, H., de Serves, C., and Cox, R. A.: Formaldehyde production in clean marine air, Geophys. Res. Lett., 24, 401-404, 1997.

Bossolasco, A., Farago, E. P., Schoemacker, C., and Fittschen, C.: Rate constant of the reaction between $\mathrm{CH}_{3} \mathrm{O}_{2}$ and $\mathrm{OH}$ radicals, Chem. Phys. Lett., 593, 7-13, 2014.

Chang, W., Lee, M., and Heikes, B. G.: One-dimensional photochemical study of $\mathrm{H}_{2} \mathrm{O}_{2}, \mathrm{CH}_{3} \mathrm{OOH}$, and $\mathrm{HCHO}$ in the marine boundary layer during Pacific Exploratory Mission in the Tropics (PEM-Tropics) B, J. Geophys. Res., 109, D06307, doi:10.1029/2003JD004256, 2004.

Fittschen, Ch., Whalley, L. K., and Heard, D. E.: The raction of $\mathrm{CH}_{3} \mathrm{O}_{2}$ radicals with $\mathrm{OH}$ radicals: A neglected sink in the remote atmosphere, Environ. Sci. Technol., 48, 7700-7701, doi:10.1021/es502481q, 2014.

Ganzeveld, L. and Lelieveld, J.: Dry deposition parameterization in a chemistry general circulation model and its influence on the distribution of reactive trace gases, J. Geophys. Res., 100, 20999-21012, 1995.

Ganzeveld, L., Lelieveld, J., and Roelofs, G.-J.: Dry deposition parameterization of sulfur oxides in a chemistry and general circulation model, J. Geophys. Res., 103, 5679-5694, 1998.

Heikes, B. G., Lee, M., Bradshaw, J., Sandholm, S., Davis, D. D., Crawford, J., Rodriguez, J., Liu, S., McKeen, S., Thornton, D., Bandy, A., Gregory, G., Talbot, R., and Blake, D.: Hydrogen peroxide and methylhydrogenperoxide distributions related to ozone and odd hydrogen over the North Pacific in the fall of 1991, J. Geophys. Res., 101, 1891-1905, 1996.

Helmig, D., Lang, E. K., Bariteau, L., Boylan, P., Fairall, C. W., Ganzeveld, L., Hare, J. E., Hueber, J., and Pallandt, M.: Atmophere-ocean ozone fluxes during the TexAQS 2006, STRATUS 2006, GOMECC 2007, GasEx 2008 and AMMA 2008 crusies, J. Geophys. Res., 117, D04305, doi:10.1029/2011JD015955, 2012.

Hosaynali Beygi, Z., Fischer, H., Harder, H. D., Martinez, M., Sander, R., Williams, J., Brookes, D. M., Monks, P. S., and Lelieveld, J.: Oxidation photochemistry in the Southern Atlantic boundary layer: unexpected deviations of photochemical steady state, Atmos. Chem. Phys., 11, 8497-8513, doi:10.5194/acp-118497-2011, 2011.

Jacobi, H.-W. and Schrems, O.: Peroxyacetyl nitrate (PAN) distribution over the South Atlantic Ocean, Phys. Chem. Chem. Phys., 1, 5517-5521, 1999. 
Jöckel, P., Sander, R., Kerkweg, A., Tost, H., and Lelieveld, J.: Technical Note: The Modular Earth Submodel System (MESSy) - a new approach towards Earth System Modeling, Atmos. Chem. Phys., 5, 433-444, doi:10.5194/acp-5-433-2005, 2005.

Jöckel, P., Tost, H., Pozzer, A., Brühl, C., Buchholz, J., Ganzeveld, L., Hoor, P., Kerkweg, A., Lawrence, M. G., Sander, R., Steil, B., Stiller, G., Tanarhte, M., Taraborrelli, D., van Aardenne, J., and Lelieveld, J.: The atmospheric chemistry general circulation model ECHAM5/MESSy1: consistent simulation of ozone from the surface to the mesosphere, Atmos. Chem. Phys., 6, 50675104, doi:10.5194/acp-6-5067-2006, 2006.

Jöckel, P., Kerkweg, A., Pozzer, A., Sander, R., Tost, H., Riede, H., Baumgaertner, A., Gromov, S., and Kern, B.: Development cycle 2 of the Modular Earth Submodel System (MESSy2), Geosci. Model Dev., 3, 717-752, doi:10.5194/gmd-3-717-2010, 2010.

Junkerman, W. and Stockwell, W.: On the budget of photooxidants in the marine boundary layer of the tropical South Atlantic, J. Geophys. Res., 104, 8039-8046, 1999.

Kerkweg, A., Buchholz, J., Ganzeveld, L., Pozzer, A., Tost, H., and Jöckel, P.: Technical Note: An implementation of the dry removal processes DRY DEPosition and SEDImentation in the Modular Earth Submodel System (MESSy), Atmos. Chem. Phys., 6, 4617-4632, doi:10.5194/acp-6-4617-2006, 2006a.

Kerkweg, A., Sander, R., Tost, H., and Jöckel, P.: Technical note: Implementation of prescribed (OFFLEM), calculated (ONLEM), and pseudo-emissions (TNUDGE) of chemical species in the Modular Earth Submodel System (MESSy), Atmos. Chem. Phys., 6, 3603-3609, doi:10.5194/acp-6-3603-2006, 2006b.

Kieber, R. J., Cooper, W. J., Willey, J. D., and Avery Jr., G. B.: Hydrogen peroxide at the Bermuda Atlantic Time Series Station. Part 1: Temporal variability of atmospheric hydrogen peroxide and its influence on seawater concentrations, J. Atmos. Chem., 39, 1-13, 2001.

Klippel, T., Fischer, H., Bozem, H., Lawrence, M. G., Butler, T., Jöckel, P., Tost, H., Martinez, M., Harder, H., Regelin, E., Sander, R., Schiller, C. L., Stickler, A., and Lelieveld, J.: Distribution of hydrogen peroxide and formaldehyde over Central Europe during the HOOVER project, Atmos. Chem. Phys., 11, 4391-4410, doi:10.5194/acp-11-4391-2011, 2011.

Lazarus, A. L., Kok, G. L., Gitlin, S. N., and Lind, J. A.: Automated fluorometric method for hydrogen peroxide in atmospheric precipitation, Anal. Chem., 57, 917-922, 1985.

Lazarus, A. L., Kok, G. L., Lind, J. A., Gitlin, S. N., Heikes, B. G., and Shetter, R. E.: Automated fluorometric method for hydrogen peroxide in air, Anal. Chem., 58, 594-597, 1986.

Lee, M., Heikes, B. G., and O’Sullivan, D. W.: Hydrogen peroxide and organic peroxide in the troposphere: a review, Atmos. Environ., 34, 3475-3494, 2000.

Lelieveld, J., van Aardenne, J., Fischer, H., de Reus, M., Williams, J., and Winkler, P.: Increasing ozone over the Atlantic Ocean, Science, 304, 1483-1487, 2004.
Levy, H. II: Normal Atmosphere: Large radical and formaldehyde concentrations predicted, Science, 173, 141-143, 1971.

O’Sullivan, D. W., Heikes, B. G., Lee, M., Chang, W., Gregory, G. L., Blake, D. R., and Sachse, G. W.: Distribution of hydrogen peroxide and methylhydroperoxide over the Pacific and South Atlantic Oceans, J. Geophys. Res., 104, 5635-5646, 1999.

O’Sullivan, D. W., Heikes, B. G., Snow, J., Burrow, P., Avery, M., Blake, D. R., Sachse, G. W., Talbot, R. W., Thornton, D. C., and Bandy, A. R.: Long-term and seasonal variations in the levels of hydrogen peroxide, methylhydroperoxide, and selected compounds over the Pacific Ocean, J. Geophys. Res., 109, D15S13, doi:10.1029/2003JD003689, 2004.

Sander, R., Kerkweg, A., Jöckel, P., and Lelieveld, J.: Technical note: The new comprehensive atmospheric chemistry module MECCA, Atmos. Chem. Phys., 5, 445-450, doi:10.5194/acp-5445-2005, 2005.

Slemr, F. and Tremmel, H. G.: Hydroperoxides in the marine troposphere over the Atlantic Ocean, J. Atmos. Chem., 19, 371-404, 1994.

Stickler, A., Fischer, H., Bozem, H., Gurk, C., Schiller, C., Martinez-Harder, M., Kubistin, D., Harder, H., Williams, J., Eerdekens, G., Yassaa, N., Ganzeveld, L., Sander, R., and Lelieveld, J.: Chemistry, transport and dry deposition of trace gases in the boundary layer over the tropical Atlantic Ocean and the Guyanas during the GABRIEL field campaign, Atmos. Chem. Phys., 7, 3933-3956, doi:10.5194/acp-7-3933-2007, 2007.

Thompson, A. M.: The oxidizing capacity of the Earth's atmosphere: Probable past and future changes, Science, 256, 11571165, 1992.

Tost, H., Jöckel, P., Kerkweg, A., Sander, R., and Lelieveld, J.: Technical note: A new comprehensive SCAVenging submodel for global atmospheric chemistry modelling, Atmos. Chem. Phys., 6, 565-574, doi:10.5194/acp-6-565-2006, 2006.

Weller, R., Schrems, O., Boddenberg, A., Gäb, S., and Gautrois, M.: Meridional distribution of hydroperoxides and formaldehyde in the marine boundary layer of the Atlantic $\left(48^{\circ} \mathrm{N}-35^{\circ} \mathrm{S}\right)$ measured during the Albatross campaign, J. Geophys. Res., 105, 14401-14412, 2000.

Wesley, M. L.: Parameterization of surface resistances to gaseous dry deposition in regional-scale numerical models, Atmos. Environ., 6, 1293-1304, 1989.

Williams, J., Custer, T., Riede, H., Sander, R., Jöckel, P., Hoor, P., Pozzer, A., Wong-Zehnpfennig, S., Hosaynali Beygi, Z., Fischer, H., Gros, V., Colomb, A., Bonsang, B., Yassaa, N., Peeken, I., Atlas, E. L., Waluda, C. M., van Aardenne J. A., and Lelieveld, J.: Assessing the effect of marine isoprene and ship emissions on ozone, using modelling and measurements from the South Atlantic Ocean, Environ. Chem., 7, 171-182, 2010. 